\title{
EDYTA STEIN W ŚWIETLE IKONY
}

\section{Filozoficzny rodowód ikony}

Ikona związana jest z kulturą bizantyjską, która znajdowała się pod wyraźnym wpływem filozofii platońskiej, a nie arystotelejskiej ${ }^{1}$. Stąd przyjmuje się Platoński i neoplatoński rodowód ikony, a wraz z nim utrzymuje się przekonanie o ikonie jako nośniku treści metafizycznych i ekumenicznych zarazem. A więc przekonanie o ikonie jako wiążącej różne wyznania, a także konfliktującej je w rozmaitych sporach ikonoklastów i ikonofilów.

Dalszą konsekwencją tych przekonań jest przypisywanie ikonie roli uświęcania bytu czy wręcz jego sakralizacji. Niezliczona ilość kompendiów omawiających historię ikony wynosi ikonę Trójcy Świętej (rys. 1) na ikonę par excellence, właśnie $\mathrm{z}$ uwagi na tę sakralną rolę, która umożliwia bycie z Bogiem Trójjedynym i w Bogu Trójjedynym. Jest to też ikona wiążąca przekaz treści Starego i Nowego Testamentu jako treści objawionych: wizyta tajemniczych gości w domu Abrahama postaciująca relacje między osobami Trójcy Świętej jako niestworzony fundament bytu i jako stwórczy akt świata i bycia w nim; inaczej jeszcze: jako Logos czy Słowo Wcielone.

1 Bizancjum i Zachód. Z Jerzym Nowosielskim rozmawia Zbigniew Podgórzec, „Literatura na Świecie" 1980, nr 12, s. 15; por. też: R. Rogozińska, Ikona w sztuce XX wieku, Kraków 2009 (analiza ikony Rublowa znajduje się na s. 406); O.B.J. Alter, Ekumenizm ikony, "Arche” 1997, nr 25. 


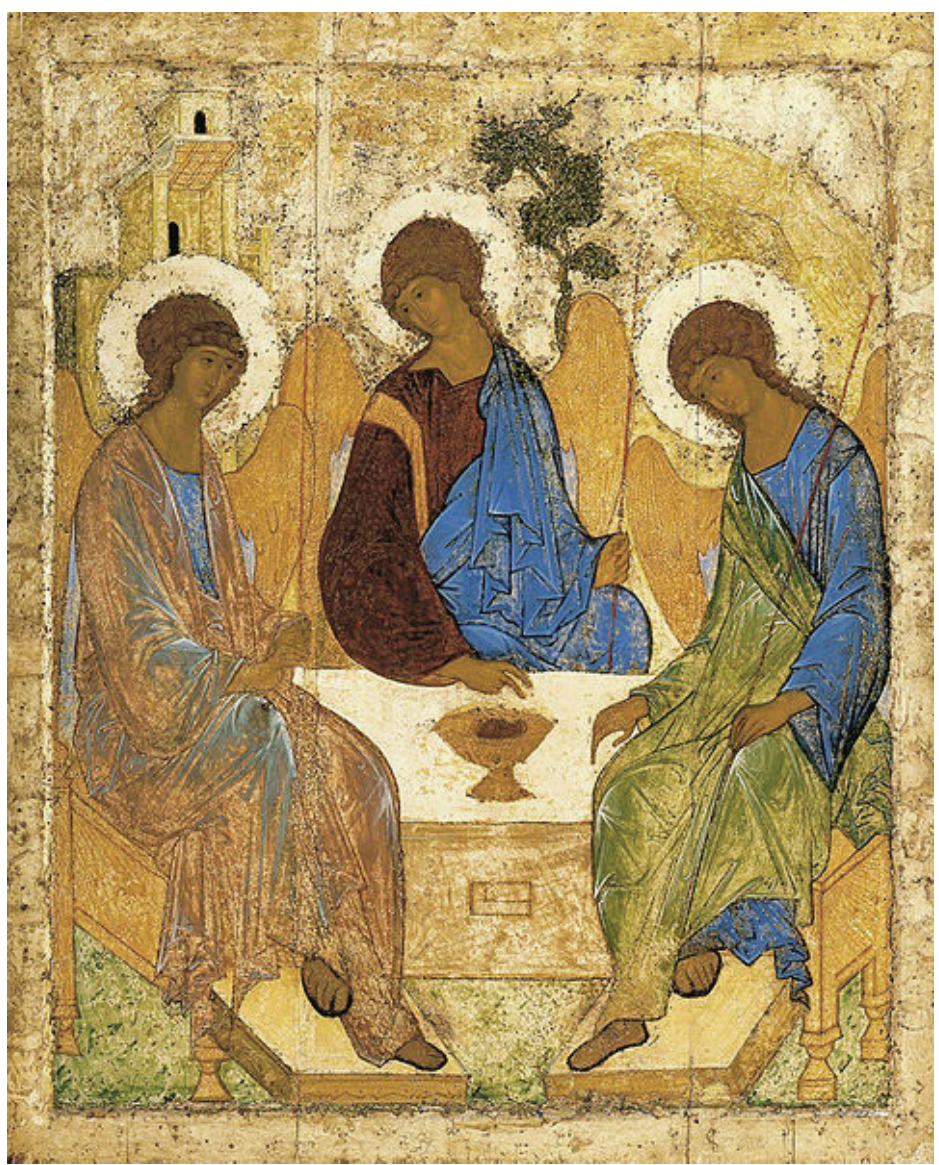

Rys. 1: Ikona Trójcy Świętej autorstwa Andrieja Rublova

Na tym samym poziomie ważności, bądź wyższym względem niego, umieszcza się Ikonę Najświętszego Oblicza (rys. 2), z dodatkowym wzmocnieniem nadnaturalnej jej mocy jako obrazu płynącej od stwory i noszy „nie ludzką ręką uczynioneej"; czyli odbicia wizerunku Chrystusa (Całun Turyński, rys. 3), wizerunku, "darowanego dla zbawienia naszych dusz", co, według wielu teologów, stanowi prawdę, że „odbicie Chrystusowego oblicza na chuście, a w ślad za nim każdy święty wizerunek, posiada podwójne znaczenie: jest obrazem i drogą zbawienia, a równocześnie został nam dany dla naszego zbawienia" 2 .

\footnotetext{
${ }^{2}$ G. Krug, Myśli o ikonie, tłum. R. Mazurkiewicz, Białystok 1991, s. 81-83.
} 
Zbawcza moc ikony, według Ojców Kościoła Siódmego Soboru Powszechnego: „Spełnia rolę świetlistej bramy prowadzącej do świata niewypowiedzianych tajemnic, rolę drogi boskiego wstępowania", a sama ikona "staje się jak gdyby widzialnym symbolem niewidzialnego, jego widzialną pieczęcią [podkr. - A.G.]"3

Trzecią co do ważności jest ikona Matki Bożej z Dzieciątkiem jako ikona Chrystusa i Bogarodzicy (rys. 4), stanowiąca „świadectwo autentyczności Wcielenia Chrystusa". Jest ona obrazem Wcielonego Boga, a także obrazem przebóstwionego człowieka. To zespolenie ikon Chrystusa i Bożej Rodzicielki wyraża istotę naszego zbawienia: "Słowo stało się ciałem, by człowieka uczynić współuczestnikiem Boskości [podkr. - A.G.]"4. Ta „zespolona” ikona pobudza do działań, które stanowią potwierdzenie prawdy o zbawieniu.

Przyjąć zatem możemy swego rodzaju gradację ważności ikon: (1) Ikona Najwiętszego Oblicza jako prototyp i źródło wszelkiego obrazu; (2) Ikona Trójcy Świętej jako Obecności Najwyższej, bytu niestworzo-

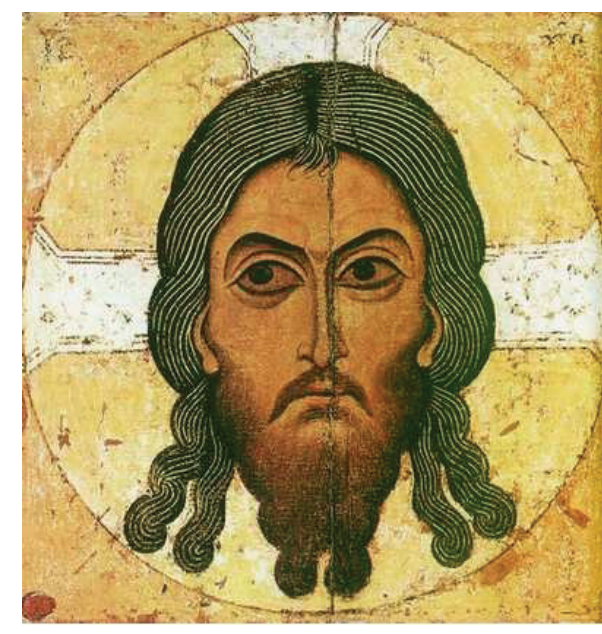

Rys. 2: Ikona Najświętszego Oblicza

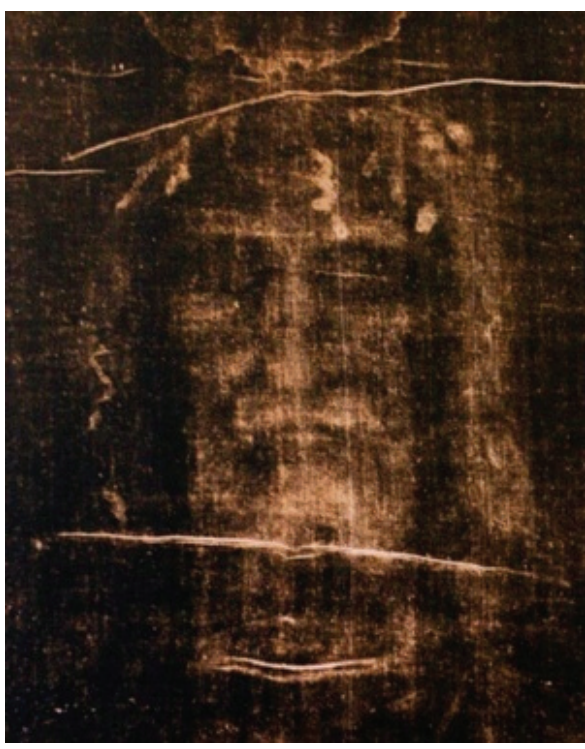

Rys. 3. Ikona „nie ludzką ręką uczyniona" (Całun Turyński)

${ }^{3}$ Tamże, s. 82. Szerzej zob. orzeczenia Ojców Kościoła na Siódmym Soborze Watykańskim dotyczące kultu świętych obrazów, np. stwierdzenie: „Podstawowy sens kultu ikon Ojcowie soboru dostrzegali nie w oddawaniu czci i adorowaniu samej materii obrazu, nie w czczeniu desek, farb czy kostek mozaiki, lecz w wysiłku wznoszenia się za pośrednictwem widzialnego obrazu do jego źródła - do niewidzialnego prototypu" (tamże, podkre. A.G).

4 Tamże, s. 82. 
nego i prototyp stwórczej relacji miłości; oraz (3) Ikona Bożej Rodzicielki z Dzieciątkiem jako Słowa Wcielonego i partycypującego w przestrzeni sakralnej człowieka - człowieka „wznoszącego się do sensu bytu”. To ostatnie sformułowanie przywołuje wprost Edytę Stein jako filozofa i osobę - postać lokującą się bezpośrednio w naszkicowanych powyżej ikonicznych rozważaniach.

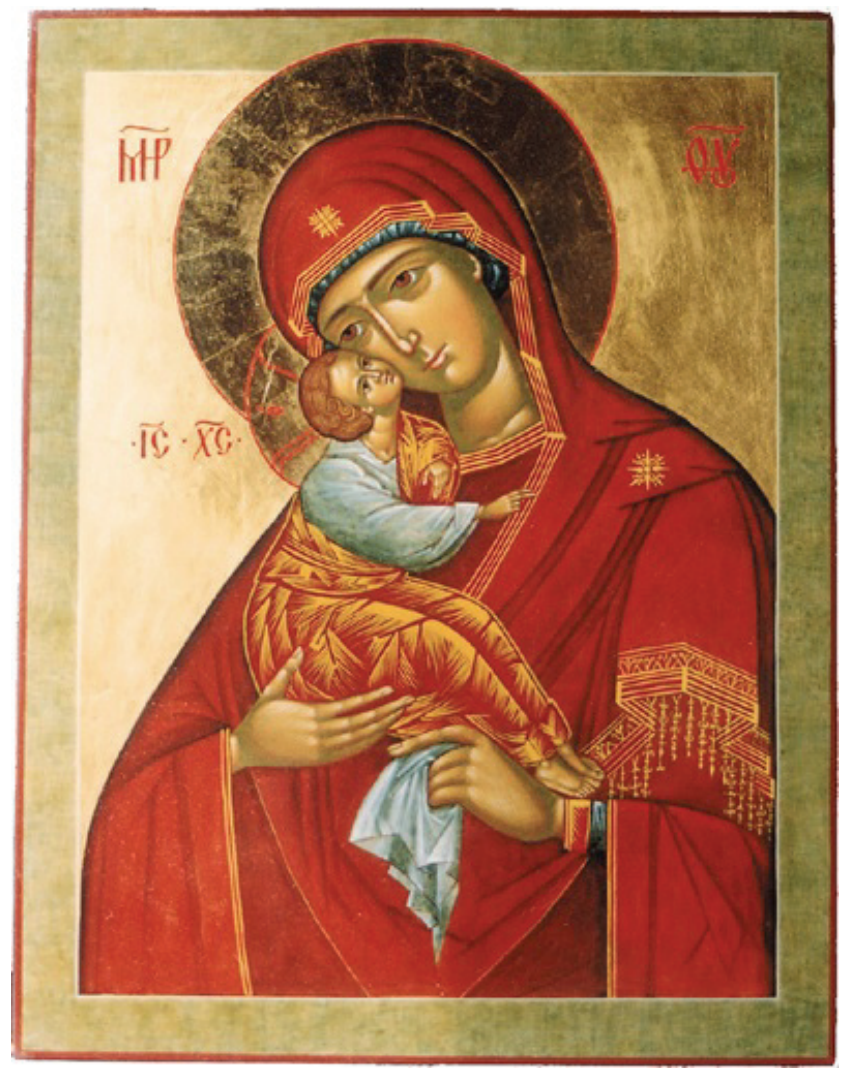

Rys. 4: Ikona Matki Bożej z Dzieciątkiem

\section{Filozofia Edyty Stein jako filozofia Światła}

Rozważeniu filozofii E. Stein jako filozofii Światła poświęciłam osobną książkę, w której starałam się uzasadnić, że jest to filozofia "skrzyżowanych dróg", linii greckiej - platońskiej i judaistyczno-chrześcijańskiej. 
To skrzyżowanie uwidacznia się $w$ autentycznym poszukiwaniu prawdy, które uskuteczniane jest $\mathrm{w}$ drodze od greckiej aletheia, prawdy widzianej, odkrywającej Absolut, do Emeth - prawdy słyszanej, objawiającej Boga. Efektem poznawczej drogi Edyty Stein jest ukonstytuowanie się koncepcji fenomenologii jako philosophia perennis z otwarciem na Transcendencję $\mathrm{i}$ jej artykulacja $\mathrm{w}$ postaci filozofii chrześcijańskiej czy antropologii teologicznej. Summa E. Stein Byt skończony a byt wieczny jest jednak nie tylko wykładem jej fenomenologicznej koncepcji, lecz ponadto zapisem poznania jako drogi "Wznoszenia się do sensu bytu" - co głosi podtytuł tej summy; jest więc próbą osiągania poznania najwyższego, forsowaniem granicy nie tylko między filozofią a wiarą, lecz także między bytem skończonym a wiecznym, i próbą dotarcia do Boga. Traktowanie filozofii jako próby ostatecznej, próby docierania do Bytu Najwyższego, niejednokrotnie zdarzało się w dziejach myśli. Praktykowali takie podejście na przykład myśliciele trynitarni par excellence, tacy jak św. Augustyn, św. Tomasz z Akwinu, św. Anzelm i inni. Może nas zadziwiać, że współcześnie to myślenie nie wygasa, a co więcej, podejmowane jest również przez świeckich myślicieli akademickich, np. przez Annę Wierzbicką, Władysława Stróżewskiego czy wcześniej Borisa Uspienskiego, Jurija Łotmana, a także znanych teologów, takich jak Paul Evdokimow, ostatnio zaś przez Tomáša Špidlika 5 .

Przywołując tę tradycję, chcę stwierdzić, że również refleksja E. Stein w nią się wpisuje, a ją samą, jako filozofa, można włączyć w grono myślicieli trynitarnych.

\section{Ikoniczne poznanie według Edyty Stein}

Nie podejmuję się w tym miejscu wyczerpującej rekonstrukcji trynitarnego rozwoju refleksji E. Stein ani wyczerpujących odwołań do wskazanej powyżej tradycji filozoficznej. Dla swej asekuracji przytoczę jedynie myśl św. Augustyna, że zrozumieć Trójcę Świętą jest „trudniej niż wyczerpać morze łyżeczką" ${ }^{6}$, i zatrzymam się na jego i św. Tomasza refleksji

5 T. Špidlik, Zanurzeni w Trójcy Świętej. Krótkie studium o Trójcy Świętej, tłum. K. Kubis, Kraków 2003.

${ }^{6}$ R. Rogozińska, analizując te wypowiedź, pisze: „Zgodnie z obrazowym wyrażeniem św. Augustyna, zrozumieć tajemnicę trzech odrębnych, a równych sobie we wszystkim osób, które są jednym, jedynym Bogiem, jest trudniej niż wyczerpać morze łyżeczką. Nic zatem dziwnego, że tajemnica «niepodzielności i niepoplątania» Bożej Trójjedni sprawiała ogromne trudności nie tylko teologom, lecz także twórcom, którzy w ciągu wieków objaśniali ją przez różne obrazy i symbole". R. Rogozińska, dz. cyt., s. 406-407. 
jako podstawie, w tym zakresie, dociekań E. Stein, jak i podstawie poznania ikonicznego - celu dociekań myślicieli trynitarnych.

Św. Augustyn ze swym dziełem O Trójcy Świętej i św. Tomasz z Traktatem o Trójcy Przenajświętszej ${ }^{7}$ wprowadzają rozróżnienia na ślad i odbicie. Rozróżnienie to służy odkryciu przez Stein nie tylko podstaw filozoficznych bytu i hierarchii stworzeń, lecz także docieczenia sensu bytu i uchwycenia poznania absolutnego. Stąd pełny tytuł jej dzieła: Byt skończony a byt wieczny. Próba wzniesienia się do sensu bytu, adekwatnie ujmuje interesującą ją i nas problematykę.

"Poszukiwanie sensu istnienia - pisze Stein - doprowadziło nas do istnienia będącego sprawcą i prawzorem wszelkiego istnienia skończonego. Odsłoniło się ono nam jako istnienie osobowe [in Person], a nawet trójosobowe [podkr. - A.G.]"8. Dalsza jej dedukcja zmierza do uchwycenia fundamentalnej relacji między Bogiem i światem przez Niego stworzonym: „Jeżeli Stwórca jest prawzorem stworzenia, to czy w stworzeniu nie musi się znajdować choćby dalekie odbicie tej trójedni istnienia pierwotnego? I czy nie ono właśnie powinno nas doprowadzić do głębszego zrozumienia istnienia skończonego? [podk. A.G.]"9. W refleksji E. Stein uwidoczniają się kwestie epistemologiczne $\mathrm{w}$ powiązaniu $\mathrm{z}$ fundamentalnymi kwestiami ontologicznymi. Z uwagi na to powiązanie uchwycony zostaje kierunek „wznoszenia się do sensu bytu": kierunek ten wypływa z doświadczeniowego, partycypującego jednoczenia się poznającego podmiotu z poznawanym bytem absolutnym - sakralnym. Nauka Objawienia i filozofia prześwietlają się nawzajem, w efekcie czego konstytuują się pojęcia hipostazy i osoby, zrozumienie objawienia o Trójosobowości Boga z jednoczesnym zrozumieniem istnienia ludzkiego i - w ogólności - tego, co rzeczywiste, jako rzeczy. W stwierdzenie o efektywności poznawczej Objawienia o Trójedynym Bogu dla poznania świata i człowieka (a więc istnienia skończonego) wpisane jest poznanie ikoniczne E. Stein, jak i rezultat finalny jej życia i dzieła. Właśnie w nim E. Stein jawi się w świetle ikony; jawi się jako fenomen świętości, najwyższego wzniesienia się do Bytu Najwyższego. Jak w zespolonej ikonie Chrystusa i Bożej Rodzicielki, która otwiera się na partycypację, na współuczestniczenie w przestrzeni sakralnej, i w tym sensie powołuje ikony świętych.

7 Św. Augustyn, O Trójcy Świętej, tłum. M. Stokowska, Kraków 1996; św. Tomasz, Traktat o Trójcy Przenajświętszej, w: tegoż, Summa Teologiczna, tłum. G. Kurylewicz, Z. Nerczuk, M. Olszewski, Kraków 2009.

${ }^{8}$ E. Stein, Byt skończony a byt wieczny, tłum. J.I. Adamska OCD, Poznań 1995, s. 369.

9 Tamże. 
Mając w pamięci całą gamę podstawowych ustaleń fenomenologicznych E. Stein, ugruntowanych $w$ filozofii perennis, jak i przefiltrowanych przez filozofię św. Augustyna i św. Tomasza, odwołajmy się do sygnalizowanego już wstępnie rozróżnienia na ślad i odbicie, które jest istotne w odniesieniu do Trójcy Przenajświętszej, a więc bytu wiecznego u Stein: „O śladzie mówi się tam, gdzie z działania wnioskuje się o przyczynowości przyczyny, o odbiciu zaś tylko wtedy, gdy $\mathrm{w}$ działaniu zawiera się przedstawienie przyczyny przez podobną jej formę". Stąd, jak uważa Stein, za św. Augustynem, „w całym stworzeniu odnajduje się ślad Trójcy, lecz Jej odbicie jedynie $w$ istotach rozumnych, obdarzonych rozumem $i$ wolą [podkr. A.G.]"10.

Trójca Święta jako prawzór odbija się w swym stworzeniu, różni się jednak od swego odbicia w sposób nieskończony, ale z niej, jako prawzoru właśnie, wyprowadza się sens odbicia ${ }^{11}$.

Odnotujmy, co z tych ustaleń jest ważne dla naszych rozważań:

1. Bóg jest przyczyną stwórczą świata i człowieka; świat i człowiek noszą Jego ślad.

2. Sens istnienia człowiek odnajduje przez odniesienie do Boga Trójjedynego, którego ślad przedstawia się w człowieku, jako odbicie, przez podobną mu formę.

3. Odkrywanie sensu istnienia człowieka doprowadza do odkrycia bytu pierwszego, którym jest byt Trójosobowy - byt sakralny - Trójca Przenajświętsza12.

4. To związanie śladu i odbicia jako relacji Boga do człowieka i człowieka do Boga ujawnia się w ikonie, przedstawieniu, które zarazem jest obecnością Boga w relacji do obecności człowieka.

5. Obecność jako wyznacznik poznania uczestniczącego (partycypacyjnego) stanowi nie tylko fundament wiary, ale i uzasadnienie dla rozumu poszukującego prawdy i sensu istnienia; stanowi prześwietlenie filozofii teologią, co nie wiąże się bynajmniej z rezygnacją z filozoficznych dociekań. Stopienie rozumu i wiary prowadzi do poznania ikonicznego, które przemienia podmiot poznający w kierunku odkrycia w sobie samym śladu Boga

\footnotetext{
10 Tamże.

11 Tamże, s. 373: „Ta odległość i niemożność ogarnięcia prawzoru nie zmienia niczego w tym, że właśnie z prawzoru wyprowadza się sens odbicia”.

12 Tamże. E. Stein pisze: „Poszukiwanie znaczenia istnienia doprowadziło nas do istnienia pierwszego: do bytu w osobie, a właściwie $w$ trzech osobach. By to zrozumieć - o ile to w ogóle jest możliwe - i by na podstawie pierwszego bytowania dojść do lepszego zrozumienia istnienia skończonego, staraliśmy się wyjaśnić, co znaczy osoba [podkr. A.G.]".
} 
i Jego jednoczesnego odbicia; to odbicie dokonuje się tylko w człowieku jako istocie rozumnej i obdarzonej wolną wolą.

6. Obecność, która jako kategoria filozoficzna odnosi się do osoby jako istoty rozumnej i duchowej zarazem ${ }^{13}$, interioryzuje, jako swą podstawę, ślad - relację przyczynowości, i odbicie - relację podobieństwa. Kategoria ta wpisuje się w: (a) fenomenologiczny personalizm ${ }^{14}$, który (b) zakłada jedność duszy i ciała, ale wynosi osobę ponad jej życie ${ }^{15}$, bo przyjmuje, że (c) „życie duchowe jest rozwijaniem się istoty w sensie uaktywniania się czegoś doskonałego w swym rodzaju istotowym"16 i w przeciwieństwie do "życia przywiązanego do materii", (d) jako ukończone i doskonałe jestestwo "wychodzi z siebie, oddaje się, nie opuszczając przez to siebie ani siebie nie tracąc".

Porównanie tych dwóch rodzajów życia prowadzi Stein do konkluzji, że "Jedno i drugie jest odbiciem mającym większy lub mniejszy «udział» w pełni życia Bożego istnienia [podkr. A.G.]"17, czyli Trójcy Świętej.

7. E. Stein odróżnia pojęcie duszy właściwe osobie, która świadomie i wolnie odnosi się do swego bytu cielesno-psychicznego (dlatego dusza, według niej, lokuje się ponad ciałem w sensie Leib, czyli jednością cielesno-psychiczną), od pojęcia duszy wegetatywnej, która tej świadomości i wolitywności jest pozbawiona, chociaż posiada życie w sensie naturalnym ${ }^{18}$.

13 Tamże, s. 376. E. Stein pisze: „Bóg, który sam w doskonałej wolności kształtuje swoje życie, a który jest całkowicie światłem (przed którym nic się nie ukryje), musi być osobą w najwyższym stopniu [podkr. A.G.]".

${ }^{14}$ A. Półtawski, Personalizm fenomenologiczny Edith Stein i Karola Wojtyty, „Kwartalnik Filozoficzny" 1995, t. XXIII, z. 1.

${ }^{15}$ E. Stein pisze: „Ludzkie Ja jest nie tylko czystym Ja i nie tylko Ja duchowym, lecz także cielesnym"; i dalej: "Istota duchowa, nie mająca ciała materialnego, jest czystym duchem, a nie duszą" (E. Stein, dz. cyt., s. 380); definicja osoby to ciało (Leib) i dusza: "gdzie jest ciało żywe, tam jest dusza" (tamże, s. 380, 383); ciało w sensie Leib należy do jedności mojej osoby; zob też: tamże, s. 390: podział na nauki przyrodnicze i nauki o duchu i dalsze dystynkcje dla pojęcia duszy.

${ }^{16}$ Dokładniej rzecz wyrażając, według E. Stein życie jest kształtowaniem materii w trzech stopniach: w przekształcaniu materiałów składowych, samokształtowaniu się i rozmnażaniu (wstępna definicja duszy jako formy istotowej wszystkiego, co żyje, i gradacja kształtowania życia przyjęta jest za Arystotelesem i św. Tomaszem z Akwinu); Stein wyróżnia, za wspomnianymi filozofami, życie przywiązane do materii (życie jako kształtowanie materii) i życie duchowe, wychodzące poza materię (tamże, s. 380-381).

17 Tamże, s. 382.

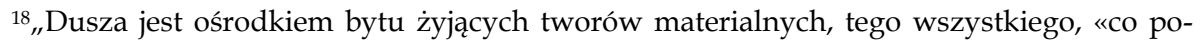
siada moc do kształtowania siebie samego», a ponadto [istnieje] bardziej różnicujące pojęcie duszy jako Gestalteinheit, które odnosi się do bytu otwierającego się ku wnętrzu, ku istnieniu w sobie samym, wspólne bytom zwierzęcym, cielesno-psychicznym [seelische] poddanym «mechanizmowi» swego życia. Dokładniej: słowo «dusza» znajduje jeszcze właściwsze zastosowanie tam, gdzie wnętrze jest nie tylko ośrodkiem i punktem wyjścia dla zewnętrznego 
A zatem w ujęciu E. Stein to $\mathrm{w}$ duszy ludzkiej następuje wyniesienie osoby ponad jej życie. Stąd życie ludzkie kształtuje się jako świadome istnienie, a człowiek staje się nosicielem swego życia; jak mówi Stein: „trzyma je w ręce".

Dusza ludzka jawi się więc jako skrzyżowanie zmysłowości i duchowości, jako pośrednik miedzy nimi. E. Stein przedstawia metaforycznie te rozważania, za Teresą z Ávila, jako „twierdzę wewnętrzną", w której dusza, jako wędrujący podmiot, nie jest punktem, jak czyste Ja, „ale stanowi «przestrzeń», $[. .$.$] «twierdzę» \mathrm{z}$ wieloma mieszkaniami, już to wychodząc na zewnątrz, już to wycofując się bardziej do wnętrza [podkr. A.G.]"19.

Dusza tak pojęta posiada własną istotę, $\mathrm{i}$ „ta właśnie istota wraz ze swą swoistością nadaje właściwe piętno ciału i wszelkiemu działaniu osobowo-duchowemu, ponadto wypływa $[\ldots]$ z niego w sposób nie uświadomiony i nie zamierzony"20. A więc dusza duchowa najpierw musi poznać swą istotę, a drogą do tego jest jej życie, bo przez poznanie siebie i przez stawanie się tym, czym być powinna, dusza "dochodzi do siebie samej"21. Z pojęciem duszy ludzkiej skorelowane jest zatem pojęcie świadomości, które rejestruje przechodzenie $\mathrm{w}$ prawdziwe rozumienie własnego życia i wszelkiego napotkanego sensu ${ }^{22}$.

E. Stein bardzo szczegółowo rozpisuje stopnie samopoznania, czyli poznania duszy. Jako pierwszy wyróżnia świadomość towarzyszącą życiu Ja („JJa ludzkie to takie Ja, którego życie wyłania się z ciemnej głębi duszy"23); jako drugi - samodoświadczenie i samoobserwację, samowychowanie poprzez stanięcie naprzeciw siebie jak naprzeciwko przedmiotu; jako trzeci doświadczanie w sposób pierwotny (contritio) głębokiej skruchy, uzdalniającej duszę do wewnętrznej odnowy ${ }^{24}$, co prowadzi do wzniesienia się jej do stopnia czwartego - odkrycia istoty duszy, czyli swej właściwości osobistej.

Zauważmy, że w refleksji Stein poznanie duszy nie zatrzymuje się na świadomym samoprzedstawieniu się (dusza jako przedmiot poznania), ale dopełnione jest przez doświadczanie, wynikające z:

\footnotetext{
kształtowania, lecz gdzie byt otwiera się ku wnętrzu; gdzie życie jest już nie tylko kształtowaniem materii, ale istnieniem w sobie samym; gdzie każda dusza stanowi «świat wewnętrzny», w sobie zamknięty, choć nie wolny od powiązań z ciałem i z całym światem rzeczywistym [podkr. A.G.]" (tamże, s. 382).

${ }^{19}$ Tamże, s. 385.

${ }^{20}$ Tamże, s. 386.

21 Tamże, s. 433.

22 Tamże, s. 431.

23 Tamże, s. 434

24 Tamże, s. 435.
} 
1) stopni samopoznania (określonych metaforycznie przez przekraczanie kolejnych mieszkań twierdzy; wiążą się z nim akty wyrzeczenia - ascezy, skruchy - oczyszczania, przemiany i odnowy);

2) pozaświadomego kierowania nią przez siłę transcendentną, która określa jej cel.

W istocie duszy spotyka się zatem, mówiąc najprościej, człowiek i Bóg, a zdobywanie twierdzy wewnętrznej ilustruje niejako pogłębiający się, coraz bardziej jednoczący charakter tego spotkania; spotkania, które nabiera pewności poznania absolutnego, bo wychodzi z immanencji samopoznania (redukuje naturalną pamięć, rozum i wolę) i wkracza w rejony transcendentne, pozaświadome, czyli jest to poznanie, w którym "dusza wychodzi z siebie”, w którym siebie przekracza. Powiedzielibyśmy, że "ogołocona”, spotyka się z Bytem Najwyższym - Absolutem (Światłem), ale ponadto poznaniu temu towarzyszą niekomunikowalne, pozapojęciowe i nadnaturalne stany duszy (zachwycenie, radość, miłość, akty heroizmu, zdolność do przekraczania naturalnych ograniczeń), co wskazuje, że Absolut ten jest "pełnią", jest "czynny”, „żywy”, „stwarzający”, „wartościonośny”, "uzdalniający” do tych stanów. A więc jest Bogiem - Prawzorem dla duszy. Stany, które dusza doświadcza, są Jego śladem i odbiciem; potwierdzają Jego moc i górującą nad wszystkimi atrybutami miłość.

Aspekty tej miłości mieszczą się w jej potrójnej, osobowej relacyjności. Stąd Bóg - Prawzór jest Trójcą Świętą, Bogiem Trójjedynym, dostępnym wyłącznie na drodze poznania miłością. Dusza nie pozna Go poza tą drogą.

Konkludując, można powiedzieć, że to istota duszy jest tym czynnikiem, który kształtuje siłę i życie duszy; czynnikiem ukierunkowującym ją na to, czym dusza być powinna, a co dane jest $\mathrm{w}$ odniesieniu do Boga, w spotkaniu z Bogiem-Miłością. A zatem sens duszy przybiera postać celu, do którego kieruje duszę jej istota - istota, która jednoczy immanencję $\mathrm{z}$ transcendencją, byt skończony i byt wieczny, wieczność z czasem, nieskończoność ze skończonością; która wznosząc się do Bytu Najwyższego, określa go jednocześnie jako swój cel i sens. Rozpoznanie istoty duszy przez E. Stein nie mieści się w psychologicznych koncepcjach (ani tych znanych E. Stein i zdecydowanie przez nią krytykowanych, ani nam współczesnych); mieści się natomiast $\mathrm{w}$ zakresie fenomenologii miłości, którą klasyczni fenomenolodzy budowali, a której współczesne dopowiedzenie znaleźć możemy w filozofii W. Stróżewskiego 25 . 2013.

${ }_{25}$ Zob. W. Stróżewski, Mała fenomenologia miłości, w: tegoż, Logos, wartość, miłość, Kraków 
Zauważmy więc, z całą mocą, że - $\mathrm{w}$ rozpoznaniu Stein - sens życia człowieka zależy od tego wszystkiego, z czym się on styka, czyli od zewnętrznych i wewnętrznych uwarunkowań (życia duszy), ale w ostateczności zależy on od Boga.

\section{Ikona jako sacramentale obecności ${ }^{26}$}

Wróćmy do zasygnalizowanej we wstępie tradycji ikony. Istnieją dwie linie ikoniczne: bizantyjska (charakterystyczna dla prawosławia, wynosząca prawzór wszelkiej ikony, ofiarowany nam przez samego Zbawcę) i judaistyczno-chrześcijańska (przedstawieniowa i nieprzedstawieniowa). Wspólną kategorią spajającą te linie jest kategoria obecności, obecności Najwyższego (Światła, Transcendencji, Boga).

Linia przedstawieniowa ewoluuje wokół ikony Trójcy Świętej jako bytu osobowego, bo „ikoną w pełni może być jedynie przedstawienie osobowe”, i ikony „nie ludzką ręką malowanej”, czyli Najświętszego Oblicza, bo:

Obrazem świętym może być zgodnie z tradycją tylko taki obraz, który przedstawia ludzkie oblicze, twarz przeobrażoną Boskim światłem. Jest to kamień węgielny wszelkiej ikony, ofiarowany nam przez samego Zbawcę $\mathbf{w}$ odbiciu Jego oblicza na chuście. Ono właśnie stanowi ikonę ikon, źródło wszelkiego świętego przedstawienia [podkr. A.G.] ${ }^{27}$.

Linia nieprzedstawieniowa, ukonstytuowana na początku $\mathrm{XX}$ wieku, a kultywująca tradycję ikonoklazmu, wysuwa argumenty spoza tradycji ikonicznej, argumenty z zakresu sztuki awangardowej:

Gdybyśmy nie mieli rewolucji sztuki nowoczesnej w malarstwie, gdyby nie było kubizmu, abstrakcjonizmu, trwalibyśmy w stosunku do sztuki bizantyjskiej na pozycjach XIX-wiecznych, kiedy sztuka bizantyjska była dla Zachodu interesująca tylko jako zjawisko archeologiczne [...]. Nie chodzi o malarzy bizantynizujących, lecz o wpływ całego świata ikony na całe myślenie artystyczne Zachodu w tym okresie ${ }^{28}$.

Dla naszych rozważań najistotniejszym stwierdzeniem $\mathrm{w}$ interpretacji tych dwóch linii artystycznych, myślowych i teologicznych, jest to, że zakładają one jako warunek sine qua non swych principiów Obecność Boga. Takim

${ }^{26}$ Por. T.D. Łukaszuk, Obraz święty - ikona w roli sacramentale obecności, w: Chrystus Wybawiający. Teologia świętych obrazów, red. A.A. Napiórkowski, Kraków 2003.

27 G. Krug, dz. cyt., s. 34.

${ }^{28}$ Bizancjum i Zachód..., dz. cyt., s. 21-22. Jerzy Nowosielski i Jan Berdyszak to dwaj malarze ikon myślący w kategoriach nieprzedstawieniowości ikony. Por. też: A. Grzegorczyk, Humanistyka i obecność, Poznań 2014. 
syntetyzującym też ujęciem - łączącym obie linie - jest refleksja Stein, w której wyraźnie da się odczytać nakierowanie na tę Obecność jako cel poznania - odkrycie Prawdy Jedynej (Bóg jest Prawdą), i potwierdzenie przez doświadczanie - pewności, jasności i oczywistości tego poznania. Dla utwierdzenia się $\mathrm{w}$ tym przekonaniu wystarczy dotrzeć do jej interpretacji dzieł Dionizego Areoapagity, w której podnosi ona kwestię wizerunku, i odwołać się do jej praktyk modlitewnych przed konkretnymi wizerunkami-ikonami, na przykład Sedes Sapientiae z Trewiru, czy świętych, na przykład św. Franciszka z Asyżu. Dlatego też E. Stein powie: „«Najwłaściwsze» zrozumienie Boga posiada oczywiście ten, kto Go doświadczył. Rozumie on wymowę symboli i może w «portrecie» rozpoznać swego Boga, którego «zna osobiście» [podkr. A.G.]"29. Niemniej jednak Stein twierdzi też, że jej modlitwie nie musi towarzyszyć ikoniczny symbol. Rozległą kwestię poznania symbolicznego i teologii symbolicznej u Stein pomijam, ograniczając się tylko do zaakcentowania mocy poznawczej symbolu oraz jego epistemologiczno-ontologicznych wiązań różnych poziomów rzeczywistości, w tym widzialnej i niewidzialnej, co bezpośrednio wiąże się z problematyką poznania ikonicznego i traktowania w nim ikony jako symbolu. Ustalmy jedynie, że w teologii tej, ale również poza nią, ikona jest obecnością, a symbol nie tylko komunikuje, ale uobecnia, „czyni rzeczy obecnymi” (P. Ricoeur ${ }^{30}$ ). Stąd ikona nie przedstawia Boga, ona Go uobecnia. Ikona gwarantuje ontologiczne uczestnictwo człowieka w Bogu (by odwołać się do obecnych u Stróżewskiego pojęć symbolu i methexis) ${ }^{31}$.

\section{Klucze poznania}

Biada wam, uczonym w prawie, bo wzięliście klucze poznania; samiście nie weszli, a przeszkodziliście tym, którzy wejść chcieli [Ł 11,52].

E. Stein w swym poznaniu ikonicznym wzięła te klucze, które otwierają zasuwę dzielącą niebo i ziemię - transcendencję i immanencję. Weszła, z całym radykalizmem poszukującego autentycznie prawdy, w poznanie najwyższe, jednocząc się przez mądrość Krzyża z Bogiem Trójjedynym. Wskazała poznawczo możliwości „wznoszenia się do sensu bytu”

${ }^{29}$ E. Stein, Teologia symboliczna, w: tejże, Z własnej głębi, t. 1, tłum. J.I. Adamska OCD, Kraków 1978

30 P. Ricoeur, Symbol daje do myślenia, w: tegoż, Symbolika zła, tłum. S. Cichowicz, M. Ochab, Warszawa 1986.

31 W. Stróżewski, Mimesis i methexis, w: tegoż, Wokót piękna, Kraków 2002; tenże, Symbol i rzeczywistość, w: tegoż, Istnienie i sens, Kraków 1994. 
i poprzez swe życie podporządkowane rozpoznanemu, transcendentnemu celowi, te możliwości zaświadczyła i równocześnie dała świadectwo Obecności najwyższej.

Inaczej mówiąc - tak jak myśliciele trynitarni została wciągnięta do wnętrza swej duszy, w której, jak w każdej innej, mieszka Trójca Święta; w której, choć utajony, jest obecny Bóg32. E Stein powie wprost o myślicielach trynitarnych: „Zostali oni [...] wciągnięci w największą głębię duszy przez coś, co działało z większą siłą niż cały świat. Doświadczyli tam wsparcia nowego, potężnego, wyższego życia - życia nadprzyrodzonego, boskiego [podkr. A.G.]"33. Przez to wciągnięcie „zakotwiczyli” oni istnienie swej duszy w Bogu i stali się świętymi filozofami, wchodząc w siebie, znaleźli w sobie ślad Boga ${ }^{34}$ i stali się odbiciem Trójjedynego Boga.

E. Stein szczegółowo rozważa kwestię rodzajów odbicia. Dzieli je na naturalne i nadnaturalne:

a) naturalne - czyli similitudo Dei („,Bóg stworzył człowieka na swój obraz"); Bóg-Stwórca jest Bogiem w Trójcy; człowiek jako Jego odbicie nosi w sobie Jego obraz - relacje wynikające z relacji Osób w Trójcy Świętej35;

b) nadnaturalne odbicie Boga w duszy - poprzez zamieszkanie Boga w niej ${ }^{36}$.

Z rozróżnienia tego wynika, że podstawowe prawo życia duchowego to partycypacja w jedności Trójcy Świętej. Życiem Trójcy jest miłość (we wza-

32 E. Stein, Byt skończony..., dz. cyt. s. 445.

33 Tamże s. 444. Por. też: „W przedstawieniu Trzech Aniołów obraz Świętej Trójcy osiąga najwyższą z możliwych pełnię wyrazu: wszystkie Trzy Osoby posiadają tu pełnię ludzkiej godności, wyrażoną w obliczach i szatach charakterystycznych dla człowieka. Nie są to bowiem szaty anielskiej liturgii: stichariony, narękawki, lecz typowo ludzkie: długie suknie, tuniki i chitony. Skrzydła aniołów są jednak gęsto przenizane złocistymi promieniami, a ich oblicza i ułożenie włosów noszą znamię anielskiej chwały, świadczą o nieziemskiej naturze trzech posłańców, równych sobie $\mathrm{w}$ dostojeństwie, czego nie spotyka się w żadnym innym przedstawieniu Trójcy" (G. Krug, dz. cyt., s. 34).

${ }^{34}$ E. Stein, Byt skończony..., dz. cyt., s. 447; por. przypadek fenomenologów w interpretacji T. Gadacza: Świętość bycia filozofem, „Tygodnik Powszechny”, nr 3 z 17 stycznia 1999 r.

35 Warto rozszerzyć tok rozumowania w odniesieniu do obrazu Boga w naturalnym życiu człowieka. Według Edyty Stein, w obrazie tym zawarte są dwie trójjednie: duch - miłość poznanie i pamięć - rozum - wola. Rozpoznawane są one częściowo przez filozofię w tak zwanym nakazie delfickim "Poznaj samego siebie” czy we współczesnej psychologii w triadzie: myślenie - czucie - chcenie. E. Stein w swych ustaleniach, mając to na uwadze, podąża wyraźnie tropem św. Augustyna, dla którego Bóg (Trójca Święta) jest miłością, a „miłość jest sprężyną myślenia”. Jak pisze w Bycie skończonym...: „Wypełniając przykazania boskie, zdobywamy głębsze poznanie Boga, a to znów pomnaża miłość” (s. 451). Ten trop prowadzi ją do poznania uczestniczącego, w którym mamy do czynienia z przenikaniem się podstawowych form życia: poznania-miłości i woli. Ich wzajemne przenikanie się czyni je - mimo ich różnorodności - obrazem trójjedni

${ }^{36}$ E. Stein, Byt skończenia..., dz. cyt., s. 457. 
jemnej miłości osób boskich, w oddającym się boskim istnieniu) i takie jest istotowe życie człowieka na zasadzie similitudo Dei, z tym że: „W skończonym odbiciu rozszczepia się to, co $\mathrm{w}$ boskim prawzorze jest jednością [podkr. A.G.]"37.

$\mathrm{Z}$ „troistości” człowieka, które to pojęcie Stein przyjmuje za św. Augustynem, wynika jednak, że: „Aby być odbiciem Odwiecznego, duch musi się kierować ku temu, co wieczne: pojąć to wiarą, zachować w pamięci, ogarnąć wolą w miłości [podkr. A.G.]"38.

„Nie istnieje przecież żaden sens - pisze E. Stein - który nie miałby swej wiecznej ojczyzny w Logosie" 39 . Tak więc Logos (Słowo Wcielone, Chrystus) jawi się jako łącznik między życiem wiecznym a czasowym, skończonym. Jej powszechnie znana wypowiedź o Logosie jako harmonii demonstruje similitudo Dei i relację odbicia Trójjedni w stworzeniu, bytu nieskończonego $\mathrm{w}$ bycie skończonym ${ }^{40}$.

\section{Edyta Stein w świetle ikony}

Ikona to stworzone odbicie niestworzonej Trójjedni. Boris Bobrinskoy w tekście Ikona sakramentem królestwa sugeruje już samym tytułem swego szkicu „dynamiczną koncepcję ikony jako konkretnego ujawnienia sakramentalności Kościoła" 41 .

Jakkolwiek mówienie o ikonie jako sakramencie wpisuje się bezpośrednio w teologię prawosławną, można wyjść poza siatkę etykietujących ją pojęć i - jak chce Bobrinskoy - „wejść w kontemplację tajemnic uobecnianych w ikonie". I dalej - do czego prowadzi też mój wywód - w oparciu o doświadczenie religijne stwierdzić, „że ikona jest sakramentem, czyli sposobem obecności i udzielania się bosko-ludzkiej rzeczywistości Chrystusa [podkr. A.G.]”. Fundament chrystologiczny, a dokładniej „inkarnacyjny”, ikony i jego poszerzenie do zbawczego dzieła Chrystusa nadaje ikonie wymiary trynitarne. Tym samym uruchamia też relację podobieństwa między niestworzoną Trójcą i stworzonym człowiekiem. Jak konstatuje się na gruncie teologicznej ikonologii: „Od momentu wywyższenia człowieczeństwa Chrystusa język i sztuka mogą być ochrzczone w kościele, zdobywając w ten

\footnotetext{
37 Tamże , s. 453.

38 Tamże, s. 455.

39 Tamże, s. 446.

40 Tamże, s. 148.

${ }^{41}$ B. Bobrinskoy, L'icône sacrament du Royaume, cyt. za: T.D. Łukaszuk, dz. cyt., s. 64.
} 
sposób w ogniu Ducha Świętego zdolność do przekazywania naszym zmysłom i naszej inteligencji Boga w nim samym lub w jego świętych" 42 . E. Stein w swej summie ontologicznej i koncepcji antropologii teologicznej dowodzi odbicia niestworzonej Trójjedni w człowieku i jej uobecniania przez sakramenty, takie jak chrzest, Eucharystia i małżeństwo ${ }^{43}$.

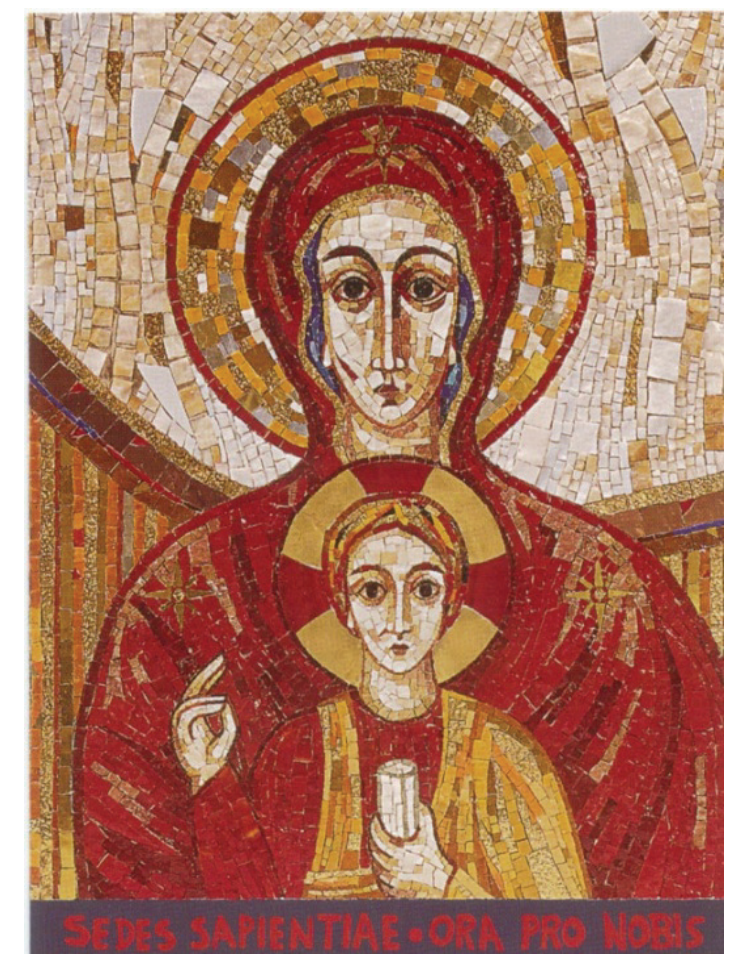

Rys. 5: Ikona Sedes Sapientiae (Stolicy Mądrości)

A zatem E. Stein łączy w poznaniu uczestniczącym rozum i wiarę, aż do osiągnięcia zjednoczenia z Bogiem Trójjedynym. To zjednoczenie dokonuje się w ikonie Świętego Oblicza, Trójcy Przenajświętszej i Sedes Sapientiae (rys. 5) ${ }^{44}$. W ich Obecności E. Stein przemienia się w świętą Teresę Benedyk-

42 Tamże, s. 65; tak uważa B. Bobrinskoy i relacjonujący jego wywód Łukaszuk; tak też twierdził św. Jan Damasceński, którego wywody są podstawą tej teologii.

${ }^{43}$ E. Stein, Byt skończony..., dz. cyt. Por. taż, Czym jest czlowiek? Antropologia teologiczna, tłum. G. Sowiński, Kraków 2012.

${ }^{44}$ Reprodukcję tej ikony E. Stein otrzymała od swoich przyjaciół na pamiątkę jej pobytu i modlitw przed tą ikoną w kościele pod wezwaniem św. Mateusza w Trewirze (10.08.1933 r.) Jak sama pisze: „Dziękuję wam gorąco za piękny obrazek. Byłam w Trewirze 10 i 11 sierpnia i 
tę od Krzyża. W ich Obecności, czyli „całkowitym Świetle”, staje się również ikoną par excellence ${ }^{45}$.

Odwołując się do teologii ikonologicznej i drogi filozoficzno-życiowej E. Stein, można powiedzieć, że „wywyższone człowieczeństwo Chrystusa”, które stanowi chrystologiczny fundament ikony, a także zaświadcza o obecności i działaniu Boga, uobecnia się także w Jego świętych. Fenomen E. Stein polega właśnie na tym ikonicznym uobecnieniu się w niej „wywyższonego człowieczeństwa Chrystusa” - jego „wcielenia i podniesienia do chwały”.

Co więcej, Bobrinskoy, opisując dokładniej fundament chrystologiczny w kierunku jego "żywotnego" łączenia się z mocą Ducha Świętego, jeszcze bardziej wyjaśnia nam fenomen E. Stein. Pisze on bowiem, że w porządku tym należy umieścić sakramentalność ikony, czyli ,jej zdolność i jej funkcję z jednej strony przenoszenia i przekazywania człowiekowi uświęcającej obecności Chrystusa i Jego świętych, a drugiej strony - wznoszenia do Boga modlitwy osobistej i zbiorowej Kościoła" 46 . Zgodnie z terminologią ikonologiczną stwierdzić można, że linia apofatyczna - wznoszenia się do Boga, i katafatyczna - przebóstwienia człowieka przez zamieszkującego $\mathrm{w}$ jego duszy Boga, spotykają się w jednoczącym poznaniu człowieka i Boga; poznaniu, które jest spotkaniem człowieka z Bogiem, człowieka z Prawda Jedyną.

Późny dorobek filozoficzny E. Stein, przeniknięty jej antropologią teologiczną, i jej konkretne życiowe wybory wskazują jednoznacznie na przybieranie przez nią postaci ikony, na jej - chciałoby się powiedzieć ikonicznienie. Wiersze E. Stein Święte oblicze i A ja pozostaję z wami. Z nowenny na zesłanie Ducha Świętego syntetyzują jej filozoficzne i religijne przekonania, które bliskie są przytoczonym myślom Bobrinskoya na temat ikony, jej przedstawieniowości, osobowego charakteru i sakramentalności, a dodatkowo wiążą się z ikoną ikon, czyli ikoną „nieludzką ręką uczynioną" - odbiciem na chuście twarzy Chrystusa, bo - jak wprost mówi Bobrinskoy ono jest źródłem „wszelkiego świętego przedstawienia” 47 . Warto też dodać, że trwanie przed obliczem Boga było wpisane w powołanie Eliasza - zało-

mogłam długo klęczeć przed tym kunsztownym i cudownym obrazem" (informacja za: D.-M. Goley, Edith Stein. Devant Dieu pour tous, Paris 2009, s. 169).

${ }^{45}$ E. Stein, Byt skończony..., dz. cyt. s. 376.

${ }^{46}$ Cyt. za: T.D. Łukaszuk, dz. cyt., s. 66.

47 Geneza wiersza: przeorysza Petra Bruning, urszulanka i przyjaciółka E. Stein, wysłała obrazek Świętego Oblicza z Turynu. Edyta, kontemplując je, stworzyła 12 grudnia 1937 roku w podziękowaniu dla niej ten poemat. Informacja za wstępem C. Rastoin w: E. Stein, Malgré la nuit. Poésies completes, Paris 2002, s. 71; por. też: B. Bobrinskoy, Myśli o ikonie, dz. cyt., s. 34. 
życiela Karmelu, i jest to również karmelitańskie powołanie - powołanie, którego dar otrzymała E. Stein ${ }^{48}$.

Zacytujmy fragmenty z tych wierszy, dla których komentarz stanowią nasze wcześniejsze ustalenia, z tą jedynie uwagą, że termin „oblicze” przyjmuje tu znaczenie Mądrości Najwyższej49, a twarz rozumiana jest jako indywidualne ukonkretnienie prawzoru. Trynitarna miłość i błogosławieństwo Ducha Świętego okazują się celem filozoficznej drogi E. Stein i jej zwieńczeniem $\mathrm{w}$ powołaniu karmelitańskim. Zaświadcza to też o judaistycznym ukorzenieniu tej filozofii, jak i reguły karmelitańskiej.

\section{Święte Oblicze}

Teraz, w tych czasach, które są ostateczne,

Odkąd znikła wiara, nadzieja i miłość bliźniego,

Ty zasłoniłeś Twoje święte Oblicze,

Oblicze tego, który cierpi na Krzyżu

I zamyka oczy , aby uśmierzyć śmierć.

Jak pod zasłoną kontemplujemy boleść

W śladach tej świętej i wysublimowanej twarzy.

Jak wielkie, jak niezmierzone jest to cierpienie,

Że nie możemy go ani pojąć, ani przeniknąć jego tajemnicy.

A jednak oddałeś ducha w ciszy i pokoju

I moc była w Tobie

Aby pomieścić to cierpienie bez miary.

Ty byłeś jego Mistrzem, całkowicie oddając się mu.

W pokoju o niespotykanej głębi wydobywa się

Promień śladów Twej twarzy

I słowo: Wypetnito się.

Jeśli kogoś połączysz ze sobą na wieczność

Ty go ukrywasz pod zasłoną tajemnicy:

On uczestniczy w Twoich cierpieniach

I cierpi jak Ty,

Ukryty w ciszy, w głębokim pokoju 50

48 Zob. M. Zawada, Ogrody rozmodlenia. Charyzmat karmelitański, Kraków 2008; tenże, Antologia karmelitańska, Kraków 2005; Mikołaj z Narbonne, Płonąca strzała, tłum. J. Zieliński, Kraków 1994; zob. też: N. Przybylska, Odwaga świadomości (w niniejszym tomie).

49 Nie traktuję więc go synonimicznie z terminem "twarz" (konkretyzowanie oblicza w ludzkim myśleniu i działaniu), jak to czyni Słownik terminologii chrześcijańskiej, Poznań 1971.

${ }^{50}$ E. Stein, Malgré la nuit, dz. cyt., s. 71-75 (podkreślenie i przekład - A.G.). 
A ja pozostaję z wami

Z nowenny na Zestanie Ducha Świętego

1. Kim jesteś słodkie Światło napełniające mnie i rozświetlające mroki mego serca?

$[\ldots]$

6. Czyż nie jesteś stwarzającym jasne zwierciadło, najpierw tronu Najwyższego, podobny do morza kryształu, w nim Bóstwo przygląda się sobie z miłością? Pochylasz się nad stworzeniem, Twoim najpiękniejszym dziełem i promieniując odbija się w Tobie Twój blask.

A wszelkich istot czysta piękność jednoczy się w cudownej postaci dziewicy, Twojej oblubienicy bez skazy Duchu Święty - Stworzycielu Wszechświata!

7. Czyż nie jesteś słodką pieśnią miłości oraz świętej bojaźni, rozbrzmiewającej wiecznie przed Trójjedynym Tronem oraz jednoczącej w sobie czysty dźwięk wszelkich istot? Harmonia, która łączy członki z głową, w niej każdy odnajduje uszczęśliwiony tajemny sens swojego jestestwa.

Radując się powraca

wolny do Twojego strumienia

Duchu Święty - Wieczna Radości! 51

\section{Oblubienica Ducha Świętego}

Przez nierozerwalną więź ona jest Twoją Oblubienicą, O Duchu spokoju, w końcu Cię znalazłam:

Ukazujesz mi blask Twojej Boskości

W promieniującej twarzy Maryi.

O Duchu łagodności,

${ }^{51}$ E. Stein, A ja pozostaję z Wami, tłum. Z. Naumowicz, w: J.I. Adamska OCD, Mądrość Miłości. Rzecz o duchowości Edyty Stein, Tczew - Peplin 1998; wiersz powstał w Echt, w maju $1941 \mathrm{r}$. 
Znalazłam Cię

Objawiasz mi się

Świetliście w obliczu

Maryi ${ }^{52}$.

Zacytowane wiersze syntetyzują filozofię E. Stein. Określić ją można jako dynamiczne zmierzanie $w$ kierunku poznania ikonicznego - poznania dążącego do osiągnięcia stopnia absolutnego zjednoczenia z poszukiwaną prawdą jedyną, czyli Bogiem Trójjedynym. W autentyczności i rzeczywistości tego poznania E. Stein staje się ikoną $\mathrm{w}$ dosłownym tego słowa znaczeniu zostaje "wywyższona do chwały Chrystusa". Moc tego wywyższenia ujawnia się $\mathrm{w}$ jej nadnaturalnym promieniowaniu, które przesądza o istocie jej fenomenu.

\section{Konkluzje}

1. Refleksja E. Stein w swym całościowym przesłaniu wykazuje niekonfliktowość problemu rozumu i wiary, a tym samym łączliwość filozofii i teologii, czy mocniej: możliwość prześwietlenia filozofii teologią. Stopienie filozofii i wiary, zamiast oddzielania grubą kreską fides i ratio, niesie ważkie konsekwencje dla ostatecznego kształtu dzieła E. Stein, który przybiera postać antropologii teologicznej czy chrześcijańskiej.

2. Antropologia ta kreśli zręby uprawiania filozofii partycypacji z wyraźnie nakreślonym celem poznania najwyższego, poznania, którego finałem jest bycie w przestrzeni sakralnej, w której obecność poznającego podmiotu spotyka się z Obecnością Boga. Ta partycypacja umożliwia dotarcie do Prawdy Jedynej, będącej kresem możliwości poznania ludzkiego, a zarazem sensem ziemskiej drogi człowieka, jak i istotą jego człowieczeństwa. Antropologia chrześcijańska E. Stein jest chrystocentryczna, a swój fundament buduje na naśladownictwie Chrystusa ujętym w mądrości Krzyża, która przekazuje zarówno treści objawione, jak i praktyczne wskazówki "Wznoszenia się do sensu bytu" i osiągnięcia tym samym poznania najwyższego.

3. Możliwości tego poznania, tkwiące w symbiozie filozofii i wiary, zakładają kategorię obecności jako kategorię aktywizującą dążność do autentycznego poszukiwania prawdy, celu poznawczego filozofii, i ugruntowują

52 E. Stein, Epouse de L'Esprit Saint, w: tejże, Malgré ja nuit, dz. cyt. s. 131 (przekład A.G.), wiersz pisany latem 1942 roku. 
wiarę w Obecność Najwyższą, czyli Boga. Symbioza filozofii i wiary wytycza szlak poznania partycypacyjnego, którego efekty poznawczo-egzystencjalne ujawniają się $\mathrm{w}$ trakcie jego uskuteczniania. Efekty te ściśle wiążą się $\mathrm{z}$ odkrywaniem i przemienianiem się podmiotu poznającego $\mathrm{w}$ trakcie doświadczania własnej tożsamości i sensu bytu. Jest to doświadczanie sukcesywnie pogłębiające poznanie siebie, jak i przestrzeni istotnie istniejącej przestrzeni sakralnej.

4. Odkrywanie i przebywanie $\mathrm{w}$ tej przestrzeni zapewnia doświadczanie Obecności Najwyższej, jednoczenie się z Nią i wiązanie skończonego bytu podmiotu poznającego z Bytem Nieskończonym - Wiecznym.

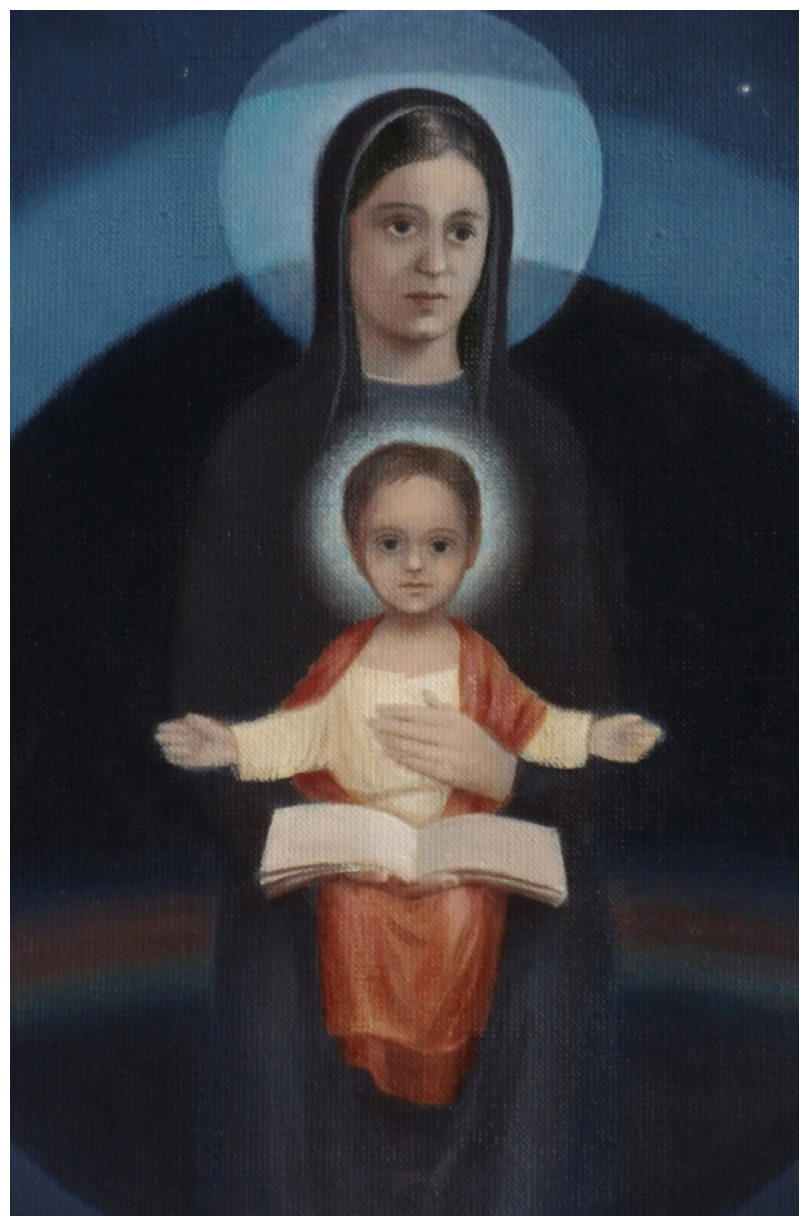

Rys. 6: Danuta Waberska, Sedes Sapientiae (ikona przedstawiająca Maryję z twarzą Edyty Stein) 
5. Symbioza poznania i egzystencji w ramach antropologii chrześcijańskiej w projekcie E. Stein przynosi to, co możemy właśnie określić jako jej fenomen:

a) E. Stein jest ikoną w sensie symbiozy sensu i obecności;

b) E. Stein jest w świetle ikony, to znaczy rzeczywiście dociera do Obecności Najwyższej;

c) partycypuje w niej; zostaje wciągnięta do jej wnętrza, w którym mieszka Trójca Święta; jest „zanurzona” w Trójcy Świętej;

d) promieniuje nią;

e) jest ikoną w świetle Najwyższego, czyli Boga: jest przed Najświętszym Obliczem, i jest ikoną $\mathrm{w}$ sensie uobecniania (przedstawiania $\mathrm{w}$ relacji odbicia, $\mathrm{w}$ relacji miłości).

f) E. Stein, jako ikona, doświadcza bytu sakralnego; jest dotknięta przez ten Byt;

g) ikona to obecność i modlitwa (modlenie się i pisanie) - „modlę się, więc jestem"; E. Stein jako ikona może wstawiać się za nami, może nas pociągać w kierunku wnętrza i światła, które jest bytem odwiecznym;

h) ikona Mądrości z twarzą E. Stein jest malarskim uhonorowaniem fenomenu E. Stein (rys. 6); Stein przebóstwia się w ikonę Matki Bożej Rodzicielki, w której uobecnia się Trójca Święta.

\section{Edith Stein in the Light of the Icon}

\section{Summary}

In this article discussed is the phenomenon of icon sui generis and a phenomenon of Edith Stein as anicon. Stein's philosophy of Light is inscribed into a philosophical lineage of the icon, especially platonic and neoplatonic, what leads to creating an idea of iconic cognition - its foundation is a connection between trace and reflection revealed in an icon which is both a representation and a presence of God. By referring to Stein's late philosophy as well as her biography the author describes a merge between those two domains which leads to an absolute, iconic cognition and therefore allows presenting Stein as an iconic figure, which power reveals itself in her supernatural emanation. This emanation as well as a symbiosis between cognition and existence creates an essence of Edith Stein's phenomenon. 